\title{
Editorial: The Possibilities and Limitations of Rights-Based Approaches to Heritage Practice
}

\section{Anne-Laura Kraak*}

\section{Bahar Aykan $^{\dagger}$}

“Can a Slum Built on a World Heritage Site in Mexico City Have Rights?" was the title of an article in The Guardian on 13 November 2015. ${ }^{1}$ The article details the precarious situation of the slum dwellers living in Xochimilco, an area of Mexico City that was designated a world heritage site in 1987 for its network of canals and artificial islands that present a testimony to the efforts of the Aztec people to build a habitat in an unfavorable environment. Since Xochimilco is a protected area, the slum dwellers can be evicted any time. As the article explains, however, in the "absence of urban planning or affordable housing" and where there is "extreme, generational poverty and rampant inequality," these inhabitants are left with few alternative locations to live. According to the 2010 Mexico City Charter for the Right to the City (based on the 2004 World Charter of the Right to the City), people have the right to "a safe place in which to live in peace and with dignity through the generation of instruments to reduce and participative spaces to control speculation, urban segregation, exclusion, and forced evictions and displacements."2 However, what rights do people have who have illegally settled and who are (involuntarily) damaging a site of outstanding universal value for humanity?

The publication of such an article in a popular news outlet like The Guardian shows how the problematic link between heritage conservation and rights is being

\footnotetext{
*Faculty of Arts and Education, Deakin University, Victoria, Australia; Email: alkraak@gmail.com ${ }^{\dagger}$ Department of Sociology, Marmara University, Istanbul, Turkey; Email: aykanbahar@gmail.com; bahar.aykan@marmara.edu.tr

${ }^{1}$ Megan Carpentier and Marta Bausells. "Can a Slum Built on a World Heritage Site in Mexico City Have Rights?” The Guardian, 13 November 2015, https://www.theguardian.com/cities/2015/nov/13/ slum-on-world-heritage-site-mexico-city-rights-xochimilco (accessed 14 January 2018).

${ }^{2}$ Mexico City Charter for the Right to the City, 2010, http://www.hic-gs.org/content/Mexico_Charter_ R2C_2010.pdf (accessed 14 January 2018), 11.
} 
recognized beyond a small group of scholars and reflects the urgency of the issue. Xochimilco is far from the only heritage site where issues of social justice and equity have been raised; they range from forced evictions and violence in the Valley of the Kings in Egypt ${ }^{3}$ to development restrictions that entrench poverty at Angkor in Cambodia. ${ }^{4}$ What is relatively new is the use of rights language to address these situations. Cultural heritage and rights have long been seen as separate issues. However, the increased visibility of cases such as Xochimilco, as well as a range of conceptual and legal developments, has made it clear that it can be very challenging to protect heritage sites without compromising rights.

This special issue of the International Journal of Cultural Property contains a selection of articles prepared for two different sessions on the theme of cultural heritage and rights that were held during the third biannual Conference of the Association of Critical Heritage Studies in Montreal, Canada, in June 2016. Taking slightly different perspectives, both sessions were concerned with the various intersections between heritage and rights and addressed questions such as:

-What are the possibilities and limitations of global frameworks to address the intersection between heritage and rights in culturally and politically diverse situations and how could these frameworks be put to work to overcome state dominance in heritage governance and resolve heritage conflicts?

- What does a right to heritage involve, who can claim such a right, and how is it translated into conservation policy and practice?

- How can rights-based approaches to conservation contribute toward bottom-up heritage identification and governance and to what extent can they provide a means to address issues of social justice in heritage contexts (whether in a legal or discursive sense)?

The five articles that are included in this special issue reflect a variety of different ways in which these questions can be answered. They need to be understood against a background of recent scholarly, legal, policy, and bottom-up initiatives regarding rights-based approaches to heritage practice, which will be briefly introduced in this editorial.

More and more governmental, intergovernmental, and non-governmental organizations across the globe are moving toward adopting rights-based approaches to heritage, and this is happening in a context of bottom-up pressures and expectations for more inclusive, democratic, and socially just forms of heritage governance. Indigenous peoples, minorities, and other disadvantaged groups are increasingly framing their demands on heritage issues in the human rights discourse in order to gain legitimacy and international support. The infamous controversy between the Mirrar people and the Australian government over uranium-mining operations

${ }^{3}$ Mitchell 2001.

${ }^{4}$ Winter 2007. 
in the world heritage-listed Kakadu National Park constitutes an early example. In addition to environmental concerns, the incident raised serious human rights issues as the Mirrar people rejected uranium extraction in Kakadu on the grounds that it would irrevocably damage their sacred sites and heritage. ${ }^{5}$

The issue was brought onto the international agenda in 1998 when a delegation of the Mirrar attended the annual United Nations Educational, Scientific and Cultural Organization's (UNESCO) World Heritage Committee session in Paris to present a complaint. ${ }^{6}$ The Committee took this complaint into consideration and sent a fact-finding mission into the area. The mission's final report concluded that ongoing mining activities would result in damage to the park's cultural and natural heritage. The report particularly supported the rights claims by the Mirrar as the traditional owners of the affected land and called on the Australian government to ensure their right to self-determination and self-government in accordance with its obligations under international and domestic human rights instruments. ${ }^{7}$ Based on the Australian government's commitment to put the mining operations on hold, the World Heritage Committee decided against inscribing Kakadu on the World Heritage in Danger List. In 2003, the operations stopped completely, owing much to the activism from the Mirrar in defense of their collective rights over ancestral land. ${ }^{8}$ The Kakadu case is a promising illustration of the ways in which bottom-up rights-based advocacy could "jump scales,"” reaching out to global institutions and influencing national levels of heritage governance.

Nevertheless, many Indigenous and other disadvantaged groups still lack the recognition and respect for their rights in relation to heritage issues and remain vastly underrepresented in decision-making processes. ${ }^{10}$ To address such challenges, the intersection between heritage and rights has increasingly been acknowledged in the last decade in international conventions for the protection of human rights and cultural heritage. The first international human rights instrument that explicitly recognized heritage rights was the United Nations (UN) Declaration on the Rights of Indigenous Peoples, which entered into force in 2007. ${ }^{11}$ While Article 31 protects Indigenous people's right to "maintain, control, protect and develop their cultural heritage," Article 11 secures the right to intangible heritage, stating that Indigenous peoples have the right to practice, maintain, and develop their cultural traditions and customs as manifested in ceremonies, designs, visual and performing arts, literature, artifacts, and archaeological and historical sites.

\footnotetext{
${ }^{5}$ Francioni 2016, 68.

${ }^{6}$ Francioni 2016, 68.

${ }^{7}$ United Nations Educational, Scientific and Cultural Organization (UNESCO) 1998, 5-6; see also vi (Recommendation 7).

${ }^{8}$ Francioni 2016, 69.

${ }^{9} \mathrm{~N}$. Smith 1993.

${ }^{10}$ Logan 2014; see also Ekern et al. 2015.

${ }^{11}$ United Nations Declaration on the Rights of Indigenous Peoples, GA Res 61/295, UN GAOR, UN Doc. A/RES/61/295, 13 September 2007.
} 
In 2009, the UN Committee on Economic, Social and Cultural Rights also recognized heritage rights in General Comment no. 21 on the Right of Everyone to Take Part in Cultural Life. ${ }^{12}$ For instance, paragraph 37 secures the right of Indigenous peoples to "act collectively to ensure respect for their right to maintain, control, protect and develop their cultural heritage." Furthermore, paragraph 49 addresses duties of states in this regard, indicating that they should ensure minorities' right to freely exercise and access to their own heritage and respect Indigenous peoples' right to maintain and strengthen spiritual relationships with their heritage.

Bahar Aykan explores the possibilities and limitations of rights-based approaches to heritage governance by discussing how activists and non-governmental organizations have appealed to international human rights instruments to prevent the construction of the Ilisu dam on the grounds that the resulting flooding of the ancient city of Hasankeyf is a form of heritage destruction. They claim that this destruction constitutes a violation of heritage rights under the International Covenant on Economic, Social and Cultural Rights and the European Convention on Human Rights, to which Turkey is signatory. ${ }^{13}$ Aykan's analysis shows that, even though both legal instruments have moved toward recognition of heritage rights as part of human rights, fundamentally, change has been slow in coming.

Several key international heritage conventions have recently incorporated references to human rights as well. The 2003 Convention for the Safeguarding of Intangible Cultural Heritage (UNESCO ICH Convention) refers to the International Bill of Human Rights in its preamble, while Article 2 states that the Convention considers solely cultural traditions and expressions that are compatible with existing international human rights instruments. ${ }^{14}$ The UNESCO ICH Convention is also noteworthy in that it introduces obligations for states parties to include communities, groups, and individuals that develop and maintain intangible heritage in decision-making processes. Article 15 calls states parties to ensure their widest possible and active participation in the governance of intangible heritage. Moreover, according to the criteria for inscription on the representative and urgent safeguarding lists, states parties are required to obtain free, prior, and informed consent from communities for nominating their intangible heritage. The Council of Europe's 2005 Framework Convention on the Value of Cultural Heritage for Society (Faro Convention) likewise links together heritage and human rights by recognizing everyone's right to benefit from, associate with, enjoy, and transmit cultural heritage of their choice as long as they respect the rights and freedoms of others. ${ }^{15}$ In addition, the

\footnotetext{
${ }^{12}$ General Comment no. 21 on the Right of Everyone to Take Part in Cultural Life, Doc. E/C.12/ GC/21, 21 December 2009.

${ }^{13}$ International Covenant on Economic, Social and Cultural Rights, 16 December 1966, 993 UNTS 3; Convention for the Protection of Human Rights and Fundamental Freedoms, 4 November 1950, 213 UNTS 222.

${ }^{14}$ Convention for the Safeguarding of Intangible Cultural Heritage, 17 October 2003, 2368 UNTS 3.

${ }^{15}$ Framework Convention on the Value of Cultural Heritage for Society, 27 October 2005, CETS no. 199.
} 
Convention brings specific obligations for public authorities to develop bottomup mechanisms in the identification and governance of cultural heritage.

Despite these developments, not all states have ratified all conventions. Emma Hill, Mairéad Nic Craith, and Cristina Clopot consider the implications of the United Kingdom's non-ratification of the UNESCO ICH Convention. They suggest that a continuing dominant understanding of heritage as something tangible can have an impact on human rights. They argue that the asylum applications of Somali Bajuni campaigners in Glasgow have been repeatedly rejected because the evidence they presented for their identity-the knowledge of their intangible cultural heritage, most notably language - was considered insufficient.

It is important to note that there is inconsistency and ambiguity in the use of the terms "rights" and "human rights." For example, The Guardian's article about Xochimilco does not mention "human rights" directly, but it is tagged under the keyword "human rights." The Mexico City Charter (2010) and the World Charter for the Right to the City (2004), to which the article refers, explicitly state that the right to the city is a human right. However, these charters are not part of international human rights legislation. ${ }^{16}$ From a legal perspective, rights and human rights are not the same: "human rights" refer to a specific set of international legal instruments, whereas "rights" include domestic legislation. However, in popular usage and understanding, the difference between rights and human rights is not that clear cut. The way the terms are used in The Guardian exemplifies this complexity.

Similarly, in the scholarly literature on cultural heritage and human rights, there are different orientations to human rights, which range from strictly legal to more discursive. For example, legal scholars have reflected on the development of the link between cultural heritage and human rights in international law. ${ }^{17} \mathrm{~A}$ more discursive approach - which may take the legal side into account to a greater or lesser extent-is taken by an interdisciplinary group of geographers, anthropologists, archaeologists, sociologists, and philosophers. Many of these debates present a reconceptualization of ethical challenges and issues of social justice around cultural heritage that are now analyzed through a human rights lens. For instance, the chapters in the volumes Cultural Heritage and Human Rights ${ }^{18}$ and Cultural Diversity, Heritage and Human Rights: Intersections in Theory and Practice ${ }^{19}$ are concerned with topics such as Indigenous rights and traditional lands, heritage in times of war, access and exclusion, memory, intellectual property rights, development, and tensions between national and local, or majority and minority, heritage.

\footnotetext{
${ }^{16}$ Mexico City Charter. The World Charter for the Right to the City, 2004, was developed by a group of civil society organizations in collaboration with UNESCO and UN Habitat and adopted at the World Urban Forum of 2004. World Charter on the Right to the City, 2004, http://abahlali.org/files/ WorldCharterontheRighttotheCity-October04.doc (accessed 19 January 2018).

${ }^{17}$ See, e.g., Prott 2001; Stamatopoulou 2007, 2012; Francioni 2008, 2011; Blake 2011, 2015; Borelli and Lenzerini 2012; Lenzerini and Vrdoljak 2014; Durbach and Lixinski 2017.

${ }^{18}$ Silverman and Ruggles 2007.

${ }^{19}$ Langfield, Logan, and Nic Craith 2010.
} 
Yet similar issues have been, and continue to be, discussed using different language, such as politics, ${ }^{20}$ ethics, ${ }^{21}$ and contestation. ${ }^{22}$

Some scholars argue specifically for the importance of non-legal approaches. For example, Rosemary Coombe and Lindsay Weiss claim that heritage scholars can only recognize the struggles of rights-based discourse and practice in heritage politics if they take an anthropological, rather than a formalist and institutional, understanding of rights: "[H]eritage scholars might explore the ways in which human rights vocabularies provide rhetorical resources with which to protest injustice, insist upon new forms of social justice, and assert distinctive understandings of human dignity in diverse social fields." 23 Maria Fernanda Escallón took such an approach in her investigation of San Basilio de Palenque in Colombia, which had its "cultural space" inscribed on UNESCO's Representative List of Intangible Cultural Heritage in 2008 and received communal land title in 2012. Collective rights claims based on social cohesion and ethnic affiliation underlie the formal recognition of Palenque's intangible cultural heritage and land title. Yet these claims coexist with individual rights claims to particular privileges and rewards based on socio-political hierarchies. Escallón's research on the use of rights discourse by various actors shows that, paradoxically, "collective and individual rights claims simultaneously create both a cohesive image of the community and a new form of inequality and hierarchy between its members."

UNESCO's flagship world heritage program has also moved toward adopting rights-based approaches for a more democratic, bottom-up, and conflict-free heritage governance. While the program has pioneered many international, national, and local efforts to identify, respect, and protect cultural heritage, it has also received notable criticisms over its top-down approach to heritage governance and lack of local participation..$^{24}$ As the abovementioned Kakadu case also demonstrates, particularly vulnerable groups, such as Indigenous peoples and minorities, have faced threats to their cultural, property, housing, and religious rights as a result of state and expert-led mechanisms. Using examples from China, Norway, Myanmar, and Australia, Logan explains how dominant ethnic and religious groups in nation-states can use the Convention Concerning the Protection of the World Cultural and Natural Heritage (World Heritage Convention) to impose their own cultures on minority groups. ${ }^{25}$ There is also a large body of literature, which critically examines forced displacements from, and restrictions of access to, culturally meaningful

\footnotetext{
${ }^{20}$ Meskell 1998; L. Smith 2004.

${ }^{21}$ Hamilakis 2007; Stone 2011; Sandis 2014; Ireland and Schofield 2015.

${ }^{22}$ Silverman 2011.

${ }^{23}$ Coombe and Weiss 2015, 53 .

${ }^{24}$ See, e.g., L. Smith 2006; Ruggles and Silverman 2009; Logan 2014; Ekern et al. 2015.

${ }^{25}$ Logan 2014, 163-64. Convention Concerning the Protection of the World Cultural and Natural Heritage, 16 November 1972, 1037 UNTS 151.
} 
places following their world heritage listings, with examples from sub-Saharan Africa, ${ }^{26}$ Cambodia, ${ }^{27}$ India, ${ }^{28}$ and Panama. ${ }^{29}$

In 2007, the Norwegian chapter of International Council on Monuments and Sites (ICOMOS) launched the "Our Common Dignity" initiative to explore ways to address these breaches of human rights in World Heritage processes. The initiative has acquired an international dimension since 2011 when the World Heritage Centre started working together with ICOMOS, the International Union for the Conservation of Nature, and the International Centre for the Study of the Preservation and Restoration of Cultural Property-as advisory bodies to the Convention-on projects, workshops, and independent case studies to propose tools and guidelines for the adoption of rights-based approaches from world heritage nomination to everyday governance. In 2015, the General Assembly of States Parties to the World Heritage Convention adopted the Policy for the Integration of a Sustainable Development Perspective into the Processes of the World Heritage Convention, which calls for states parties to guarantee the compatibility of a full cycle of world heritage processes with human rights. ${ }^{30}$ In the same year, the World Heritage Committee took another important step and amended the Convention's Operational Guidelines for the Implementation of the World Heritage Convention, requesting states parties to demonstrate, where applicable, the free, prior, and informed consent of Indigenous peoples when nominating world heritage properties. ${ }^{31}$ The timeliness of the topic is also reflected in the recently published volume World Heritage and Human Rights: Lessons from the Asia-Pacific and Global Arena, which consists of ethnographic and legal cases that explore rights issues and recent policy developments in natural and cultural world heritage sites. ${ }^{32}$

Compared to other heritage instruments (such as the UNESCO ICH Convention and Faro Convention), the formal engagement with rights in the official debates and documentation of the World Heritage Committee or its Operational Guidelines is limited, and its development is slow. However, Peter Larsen and Kristal Buckley argue that a closer look at informal dynamics and situated conversations during the annual World Heritage Committee sessions_-through event ethnography_indicates "a multitude of moments and ways through which rights and heritage issues intersect." They discuss three examples that indicate that there is much more advocacy for, and discussion about, rights-based approaches than what formal outcomes suggest.

\footnotetext{
${ }^{26}$ Chirikure et al. 2010.

${ }^{27}$ Miura 2005.

${ }^{28}$ Jalais 2007.

${ }^{29}$ Suman 2008.

${ }^{30}$ UNESCO 2015, 7.

${ }^{31}$ Operational Guidelines for the Implementation for the World Heritage Convention, Doc. WHC.15/01, 8 July 2015, http://whc.unesco.org/en/guidelines/ (accessed 10 January 2017), para. 123. ${ }^{32}$ Larsen 2018.
} 
Anne-Laura Kraak has researched the role of human rights-based approaches to world heritage conservation in the context of one particular case: the nomination of the historic and religious site of Bagan in Myanmar. She draws attention to several factors that influence the extent to which such international policies can make a difference on the ground. Besides the influence of political negotiations during the World Heritage Committee sessions and the impact of limited capacity in Myanmar to implement certain policies, she draws attention to contestations regarding the meaning of certain rights, most notably cultural, land, and development rights. There is no clear agreement about what such rights refer to in practice, and they can be in direct conflict with each other.

Thus, what do these articles tell us about the potential and limitations of rights-based approaches to heritage practice? It is clear that the extent to which engagement with rights can lead to greater justice and equity in heritage contexts is subject to several limitations. Some of them could be overcome with time; states parties can ratify conventions; international, regional, and domestic legal frameworks can be strengthened; and capacity to implement policies can be built. It is more challenging to change deeply ingrained ideas about what type of heritage is worthy of recognition and protection; to overcome systemic unequal power relations within local and global communities; and to find ways to address the influence of politics at every stage of heritage conservation practices.

Yet, the articles in this issue have also shown that the increasing solidification of the link between heritage and rights in legal and policy areas has created avenues for various affected groups to make claims and express their discontent. Moreover, beyond official policies, documentation, and law, the link between heritage and rights is increasingly part of informal dynamics in institutional contexts and the focus of on-the-ground activism that can influence decision making. This is why it is worthwhile to continue research and debate on the potential and limitations of rights-based-and other-approaches to make heritage practice more inclusive and just for everyone, from the Mirrar people in Kakadu to the slum dwellers in Xochimilco.

\section{BIBLIOGRAPHY}

Blake, Janet. 2011. “Taking a Human Rights Approach to Cultural Heritage Protection.” Heritage and Society 4, no. 2: 199-238.

Blake, Janet. 2015. International Cultural Heritage Law. Oxford: Oxford University Press.

Borelli, Silvia, and Federico Lenzerini, eds. 2012. Cultural Heritage, Cultural Rights, Cultural Diversity: New Developments in International Law. Leiden: Martinus Nijhoff Publishers.

Chirikure, Shadreck, Munyaradzi Manyanga, Webber Ndoro, and Gilbert Pwiti. 2010. "Unfulfilled Promises? Heritage Management and Community Participation at Some of Africa's Cultural Heritage Sites." International Journal of Heritage Studies 16, nos. 1-2: 30-44. 
Coombe, Rosemary J., and Lindsay M. Weiss. 2015. "Neoliberalism, Heritage Regimes, and Cultural Rights.” In Global Heritage: A Reader, edited by L. Meskell, 43-69. Chichester, UK: John Wiley and Sons.

Durbach, Andrea, and Lucas Lixinski, eds. 2017. Heritage, Culture and Rights: Challenging Legal Discourses. Oxford: Hart Publishing.

Ekern, Stener, William Logan, Birgitte Sauge, and Amund Sinding-Larsen, eds. 2015. World Heritage Management and Human Rights. London: Routledge.

Francioni, Francesco. 2008. "Culture, Heritage and Human Rights: An Introduction." In Cultural Human Rights, edited by F. Francioni and M. Scheinin, 1-15. Leiden: Martin Nijhoff Publishers.

Francioni, Francesco. 2011. "The Human Dimension of International Cultural Heritage Law: An Introduction.” European Journal of International Law 22, no. 1: 9-16.

Francioni, Francesco. 2016. "Natural Resources and Human Rights." In Research Handbook on International Law and Natural Resources, edited by E. Morgera and K. Kulovesi, 66-85. Cheltenham: Edward Elgar.

Hamilakis, Yannis. 2007. "From Ethics to Politics." In Archaeology and Capitalism, edited by Y. Hamilakis and P. Duke, 15-40. Walnut Creek: Left Coast Press.

Ireland, Tracy, and John Schofield, eds. 2015. The Ethics of Cultural Heritage. New York: Springer.

Jalais, Annu. 2007. “The Sundarbans: Whose World Heritage Site?” Conservation and Society 5, no. 3: 335-42.

Langfield, Michele, William Logan, and Máiréad Nic Craith, eds. 2010. Cultural Diversity, Heritage and Human Rights: Intersections in Theory and Practice. Abingdon: Routledge.

Larsen, Peter B., ed. 2018. World Heritage and Human Rights: Lessons from the Asia-Pacific and Global Arena. London: Routledge.

Lenzerini, Federico, and Ana Filipa Vrdoljak, eds. 2014. International Law for Common Goods: Normative Perspectives on Human Rights, Culture and Nature. Oxford: Hart Publishing.

Logan, William. 2014. "Heritage Rights: Avoidance and Reinforcement." Heritage and Society 7, no. 2: $156-69$.

Meskell, Lynn, ed. 1998. Archaeology under Fire: Nationalism, Politics and Heritage in the Eastern Mediterranean and Middle East. London: Routledge.

Mitchell, Timothy. 2001. "Making the Nation: The Politics of Heritage in Egypt." In Consuming Tradition, Manufacturing Heritage: Global Norms and Urban Forms in the Age of Tourism, edited by N. Alsayyad, 212-39. London: Routledge.

Miura, Keiko. 2005. "Conservation of a 'Living Heritage Site' A Contradiction in Terms?: A Case Study of Angkor World Heritage Site." Conservation and Management of Archaeological Sites 7, no. 1:3-18.

Prott, Lyndel V. 2001. "Some Considerations on the Protection of the Intangible Heritage: Claims and Remedies." In Safeguarding Traditional Cultures: A Global Assessment, edited by P. Seitel, 104-10. Washington, DC: Smithsonian Institution.

Ruggles, Fairchild D., and Helaine Silverman. 2009. "From Tangible to Intangible." In Intangible Heritage Embodied, edited by F. D. Ruggles and H. Silverman, 1-14. London: Springer. 
Sandis, Constantine, ed. 2014. Cultural Heritage Ethics: Between Theory and Practice. Cambridge: Open Book Publishers.

Silverman, Helaine, and Fairchild D. Ruggles, eds. 2007. Cultural Heritage and Human Rights. New York: Springer.

Silverman, Helaine, ed. 2011. Contested Cultural Heritage: Religion, Nationalism, Erasure, and Exclusion in a Global World. New York: Springer.

Smith, Laurajane. 2004. Archaeological Theory and the Politics of Cultural Heritage. Abingdon: Routledge.

Smith, Laurajane. 2006. Uses of Heritage. London: Routledge.

Smith, Neil. 1993. "Homeless/Global: Scaling Places." In Mapping the Futures: Local Cultures, Global Change, edited by J. Bird, B. Curtis, T. Putnam, G. Robertson, and L. Tickner, 87-120. London: Routledge.

Stamatopoulou, Elsa. 2007. Cultural Rights in International Law: Article 27 of the Universal Declaration of Human Rights and Beyond. Leiden: Martinus Nijhoff Publishers.

Stamatopoulou, Elsa. 2012. "Monitoring Cultural Human Rights: The Claims of Culture on Human Rights and the Response of Cultural Rights." Human Rights Quarterly 34, no. 4: 1170-92.

Stone, Peter G., ed. 2011. Cultural Heritage, Ethics and the Military. Woodbridge: Boydell Press.

Suman, Daniel. 2008. "Tamales and Bollos-Patrimonio De La Humanidad / World Heritage: Challenges Faced by Restoration Efforts in Panama City's San Felipe Historic District." Tennessee Journal of Law and Policy 4, no. 2: 403-65.

UNESCO. 1998. "Report on the Mission to Kakadu National Park, Australia, 26 October to 1 November 1998.” Doc. WHC-98/CONF.202/INF.3/Rev. http://whc.unesco.org/fr/documents/174 (accessed 10 January 2018).

UNESCO. 2015. "Policy for the Integration of a Sustainable Development Perspective into the Processes of the World Heritage Convention." Doc. WHC-15/20.GA/INF.13. http://whc.unesco.org/en/ news/1387/ (accessed 10 January 2018).

Winter, Tim. 2007. Post-Conflict Heritage, Postcolonial Tourism: Culture, Politics and Development at Angkor. Abingdon: Routledge. 